\title{
Research on the Clothing Studio Teaching Reform under the Influence of Design Competition Social Effect
}

\author{
Jiarong $\operatorname{Han}^{1}$ \\ ${ }^{1}$ Northeast Dianli University ,Jilin , Jilin 132012 China
}

\begin{abstract}
In this paper, we conduct research on the clothing studio teaching reform under the influence of design competition social effect. Clothing terminal of art design is the product turn abstract into commodities, and this is the last stage of costume design course, in the brand design studio for middle school students can get management about clothing. Our proposed method combines the social elements together with the influence of the competition which will be effective and novel. In the future, we plan to explore more related research to polish the current reform.
\end{abstract}

Keywords: Clothing Studio Teaching; Design Competition; Social Effect; Reform and Enhance.

\section{Introduction}

The rapid development of garment industry both quality put forward higher requirements for applied talents, but also to the clothing education put forward severe challenges. Reform and perfect the higher clothing professional personnel training mode, garment specialty training to master the basic theory, has a certain clothing aesthetic and design ability, skilled in plate making and craft skills, have a certain modern garment production technology management and product development innovation ability and senior applied talents of the trade marketing ability, has become the top priority. Present the design of the traditional teaching mode has not adapted to the social requirement for the design, the introduction of studio mode is imperative. In the practical operation skills of studio mode of higher vocational colleges to carry out the teaching of the course is not only beneficial to improve the students' interest in learning, more can improve the practice ability of students. Apparel vocational colleges according to the different requirements of their own has formulated the corresponding operation mode, innovation teaching methods, strengthen the communication between school and enterprise, also some directly participate in market competition, provide enterprises with the research and development of new products [1-4]. Clothing terminal of art design is the product turn abstract into commodities, and this is the last stage of costume design course, in the brand design studio for middle school students can get management about clothing, clothing of the entire production process as well as for the fabric and accessories should be how to procurement, product costing, and training of the final product display, etc. In the training process, the teacher will be introduced to the enterprise's operation mode of classroom teaching, make students learn knowledge will be applied to actual project tasks, to strengthen the students' ability of design and to enhance the teaching effect and more close to the demand of the market which will be meaningful.

For a long time, clothing, clothes, education, fashion designers on the design concept, design thinking there is some misunderstanding. Especially in the early fashion design teaching in China is basically a kind of value theory and painting education, has been to form as the main teaching content. This kind of teaching mode make students often divorced from reality, exaggerated the novel design. Clothing design competition is to cultivate students' innovation ability and the study of theory with practice, active life college students' extracurricular 
science and technology. Studio teaching pattern which causes the student to the launching of fashion design competition to promote the innovation of the dress design major students practice ability and enhance employment competitive power has played a positive role. Also deepened the importance and necessity in costume design courses teaching practice and strengthen the training of the student beginning ability which promotes the cultivation of the students' basic quality. Design competitions have the special meaning for the current education for the following reasons. (1) Cultivate students' innovative practice ability. Clothing design competition is a way of training innovative practice ability. Can not only make students have a profound experience, professional knowledge to practical application, and will expand their horizons, enhance the ability to apply. (2) It is beneficial to increase students' knowledge. Students participating in the process of which can through the network, books, and market research of the latest design, fabric reconstruction, clothing structure, clothing production of information, can understand the book in less than the actual knowledge to make the students thinking more wide further. (3) To strengthen students' practical ability. Clothing design competition requires students besides design conforms to the theme of design renderings. Also make clothes for dynamic display, which requires the students considering the design theory of colleagues. Consider the style of clothing corresponding changes. Structure processing method and the feasibility of clothing production process which will strengthen students' practical ability. Therefore, the combination is effective.

In this paper, we research on the clothing studio teaching reform under the influence of design competition social effect. Studio mode of clothing art design teaching, according to the teaching background and enterprise demand as the goal, construct work-integrated learning teaching platform, lay a foundation for the joint production and education. Clothing art design teaching mode should be adapted to the change of the social demand for talents, according to the economic development and enterprise structure in a timely manner to adjust the teaching content, using the latest theory and technology constantly updating the teaching of professional knowledge, reflect the latest development of clothing in the course. Studio teaching on how to learn advanced experience, combining the actual situation of clothing art design course teaching and the characteristics of economic development, set up to adapt to the school of professional fashion design studio teaching mode, not only to drive the clothing art design course construction has important practical significance, at the same time for the clothing discipline teaching development has a promoting role which will be shown below.

\section{Our Proposed Methodology and Reform}

The Meaning of Design Competition. Clothing design competition, the purpose of innovation as the main pursuit with the design of the connotation, make people highly ornamental performance at the same time, also provides designers with an open, fair and impartial stage. Nowadays, various clothing design competition emerge in endlessly, gave many designers a very broad space to play to their talents, excellent costume designer clothing design contest test in addition to the clothing have deep attainments, grasp the popular trend, but also suitable for the market demand and share, exquisite production process, also familiar with the fabric, can perfect the collocation of clothing. However, there are still some drawback and imperfect points of the design competition. (1) Most of the contest judge standard is not clear. In all kinds of awards in nearly three years work, the structure design of the architectural style at almost rampant, many of the "creative" detail design under the condition of the change a fabric or color can be selected even won the prize. Clothing display is clothing work for content display design domain, clothing display as one of the main form of fashion spread, 
can also be intuitive to contest judges and audience intuitive understanding and convey the designer's idea. (2) Sponsors and participants interaction between interests has not been fully tap. From the perspective of the sponsors of the competition to attract the attention of the relevant media, to improve sponsorship enterprise and brand popularity, this is the most direct factors of its sponsorship contest. For industry association, the organization clothing design competition to talented young designers, follow-up to promote the development of industry and the reserves of fresh blood to the industry. (3) Competition rules not enough comprehensive and scientific. Because most of the clothing design contest with paper rendering the intern, administrator to finished product, so make the most of the intern's shortlist for the competitors will draft entrusted to each kind of clothing production studio, to complete the structure design and technology of the finished product before making know almost nothing about such participants even won the prize in administrator and costume design work in the future is difficult to do. Therefore, we should modify the current pattern of design competition.

Clothing design competition in clothing dynamic display links to join which make the garment design competition of the content is more comprehensive, make the game more fair and more objective results. Contestants on the clothing design contest through comprehensive investigation, finally choose the excellent fashion designer must be high comprehensive quality, worthy of the name of fashion design talent. The competition will largely enhance the ability of the participants.

The Clothing Studio Teaching Pattern. Clothing studio teaching from regular clothing style, structure, process integration through the design of the practice, in view of the enterprise production and the design of the professional event at home and abroad practice two lines form a complete teaching system of teaching mode of teaching. Clothing studio teaching curriculum for the tutor responsibility system under the subject teaching and practice research. During the entire studio teaching, teaching students according to the provisions of the subject categories can be selected corpus to carry on the design from various angles of research, the responsibility of teacher to the student the whole process of design research to the practice of teaching, with a final garment works reflect the teaching effect to improve students' comprehensive design ability. Students participate in clothing design competition, can help students to improve the design capability and production level, widen our sight and exercise comprehensive ability, gain docking with the enterprise practice, but also pave the way for the students' employment. For students not shortlisted for the contest, the teacher may contact the city for the enterprise, use after school time for enterprise practice gradually improve work which apply the knowledge to practice, to exercise comprehensive ability.

According to the development trend of garment specialty in our country, strengthen the teaching skills, training students' knowledge, strength strong which have certain creativity will be the major tasks for the development of clothing in the future. At the same time, garment studio teaching practice course is a professional clothing education in China in recent years, the important means of promoting skills training. From the social point of view, students after graduation because of the lack of practical experience, ability, work adjustment period longer. From the perspective of students, most of the students' enthusiasm is not high, but prefer to do design which is interest in learning, and thus, the phenomenon of the passive learning. Looked from the overall effect of the traditional teaching, differ with the requirement of social and enterprises is still a certain distance, practice teaching means relatively backward, and combine with theory teaching is not quite close together, so that the overall effect of the traditional teaching. At the same time, garment 
design to the requirement of theory courses and practice in teaching and traditional teaching mode can't meet, if the costume design teaching as a whole, the basic teaching and professional study is the two major parts of the key of the whole. Basic teaching aims to cultivate students interested in fashion design professional, the professional study is focused on cultivating the students' practical operation ability. However, the traditional teaching mode of the two kinds of different courses in teaching and the lack of a clear distinction between won't be able to meet the learning content transition from theory to practice.

The Principles of Social Effect. Clothing studio type project teaching method has changed the traditional teaching mode of appraisal result focus too much on thought, it's that are important to the students in clothing design process. It not only cultivate the students encountered in the design difficulties, thinking, analysis and solving ability, at the same time make students gradually established itself as a clothing design professionals in the field of professional pride, sense of mission. To sum up, the costume studio project teaching method is introduced into costume design teaching process, to let the students learn professional knowledge, in the middle of the strong professional atmosphere in the design of production base of ascension practice operation skill, is the inevitable outcome of the economic and social development forward.

The studio project teaching based on the course of clothing design, integrated, and cross discipline knowledge system, from the design practice integration teaching through and perfect, with event topic and social production practice topic two lines of practice teaching research, cultivating students' professional knowledge comprehensive application ability. This studio has a complete system of teaching mode were rare in the country. We want to be in fashion design match this creative activity using creative thinking for costume language, in the process of design elements, combined with history and design with the characteristics of age and the idea of personalized language clothing.

The Clothing Design Teaching Reform. Teaching method is in order to complete the teaching task, teachers and students in the common used method, is the unity of the teaching methods and learning methods, generally speaking practice teaching is more suitable for use action-oriented teaching method. Practice teaching reform for advanced vocational clothing to address the fundamental problems is to build the life and the education, the relationship between school and society, remove, school and society, education and life from the ills of theory and practice, to achieve in life education, life in education. Teachers in the teaching practice, therefore, in addition to that meet the needs of the teaching method and practice teaching tasks outside. Also should put the students as far as possible to live, to society, causes the student to the knowledge and skills with what, life experience, build the learning environment, familiar with the knowledge and skills are easy to experience and testing, help understanding and mastering of knowledge and skills, understand the deeper, the master is stronger. As the example, in the figure one, we show the innovative application for the clothing studio teaching which is designed by the Harvard university researchers.

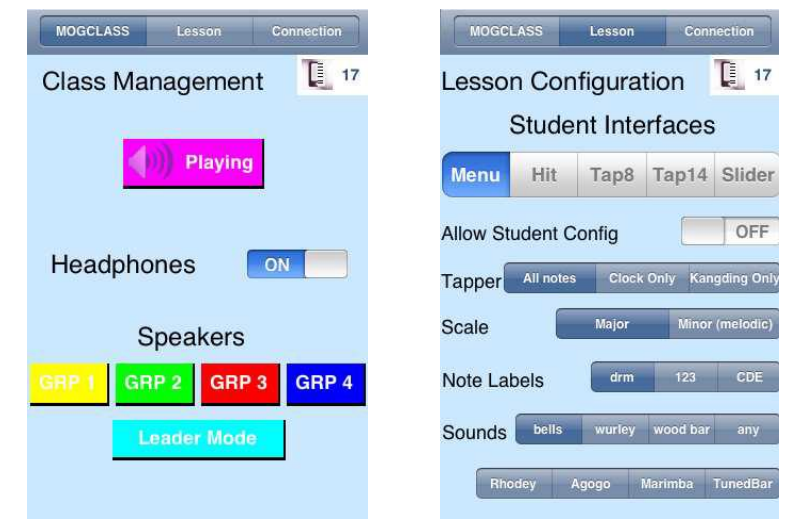

Figure 1.The Sample Application for the Reform of Clothing Studio Teaching Pattern 


\section{Conclusion}

In this paper, we conduct research on the clothing studio teaching reform under the influence of design competition social effect. Practice teaching reform on the teaching contents should reflect real life, not only in teaching management is to direct the teaching to real life. To establish the corresponding practice teaching management system and guarantee mechanism of funds, lead teachers to student life, enlarge the intersecting surface of students and teachers, widen the channel of communication between teachers and students, make the extracurricular, procedural, not easily evaluate students self-exercise can get teacher's guidance, for the cultivation of students' innovative consciousness and innovative ability to improve intelligence system and funds guarantee. In the future, we have scheduled to conduct more related research to modify the current pattern.

\section{References}

[1] Guan J. A Brief Discussion on the Teaching Reform of Clothing Design Major in Higher Vocational Colleges[J]. Science Education Article Collects, 2014.

[2] Qi X. The Bauhaus Teaching Reform of Higher Vocational Art Design Professional Studio Teaching Enlightenment[J]. Modern Industrial Economy \& Informationization, 2014.

[3] Shen S, Zhou C. A Preliminary Study on the Educational Reform of Supervisor Group Studio of Architecture Major[J]. Chinese \& Overseas Architecture, 2014.

[4] Cole S. Costume or Dress? The Use of Clothing in the Gay Pornography of Jim French's Colt Studio[J]. Fashion Theory the Journal of Dress Body \& Culture, 2014, volume 18:123-148(26). 